\title{
The predictive value of immunohistochemical markers in untreated Wilms' tumour: are they useful?
}

\author{
Mazen A. Ghanem • Theo H. van der Kwast • \\ W. M. Molenaar - Manal A. Safan • \\ Rien J. Nijman · Gert Jan van Steenbrugge
}

Received: 27 April 2007 / Accepted: 15 October 2010/Published online: 19 May 2011

(C) The Author(s) 2011. This article is published with open access at Springerlink.com

\begin{abstract}
Purpose This study reevaluates the potential role of different tumour markers as prognostic indicators in untreated nephroblastoma.

Methods Expression of a broad panel of tumour markers was investigated by means of immunohistochemical analysis in 43 WT patients. Patients were treated by radical nephrectomy and had a mean follow-up of 11.9 years.

Results Generally, all the tumour markers studied were expressed in normal kidney tissue and at variable levels in the three cell types of WT (blastema, epithelium and stroma). Immunoreactive blastemal (Bcl-X, Bcl-2 and CD44s) and epithelial (Bcl-X, Bcl-2 and MIB-1) cells were present in the majority of tumours. No correlation was found between their expression and pathological stages. Univariate analysis showed that blastemal WT-1, TGF- $\alpha$, VEGF, MIB-1 and p27 Kip1 were indicative for clinical progression. In a multivariate analysis, WT-1 protein
\end{abstract}

\section{A. Ghanem}

Department Urology, Josephine Nefkens Institute, University Medical Center Rotterdam, Rotterdam, The Netherlands

e-mail: mazenghanem@yahoo.com

M. A. Ghanem

Department Urology, Menoufiya University,

Shebin El-Kom, Egypt

T. H. van der Kwast

Department Pathology, Josephine Nefkens Institute,

University Medical Center Rotterdam, Rotterdam,

The Netherlands

e-mail: theodorus.vanderkwast@uhn.on.ca

W. M. Molenaar Department Pathology, University Medical Center Groningen,

Groningen, The Netherlands expression by blastemal cells was an independent prognostic marker for clinical progression.

Conclusions The blastemal WT-1, TGF- $\alpha$, VEGF, MIB-1 and $\mathrm{p} 27 \mathrm{Kip} 1$ expression correlate with clinical progression in untreated nephroblastoma. Therefore, their expression may be of value in identifying patients with a high propensity to develop distant metastases.

Keywords Wilms' tumour - Immunohistochemsitry · Untreated · Tumour markers · Prognosis

\section{Introduction}

Wilms' tumour (WT) is one of the most common solid tumours in children, with a frequency of 1 in 10,000 live births. The most important predictors of treatment failure for children with WT are tumour histology and stage of

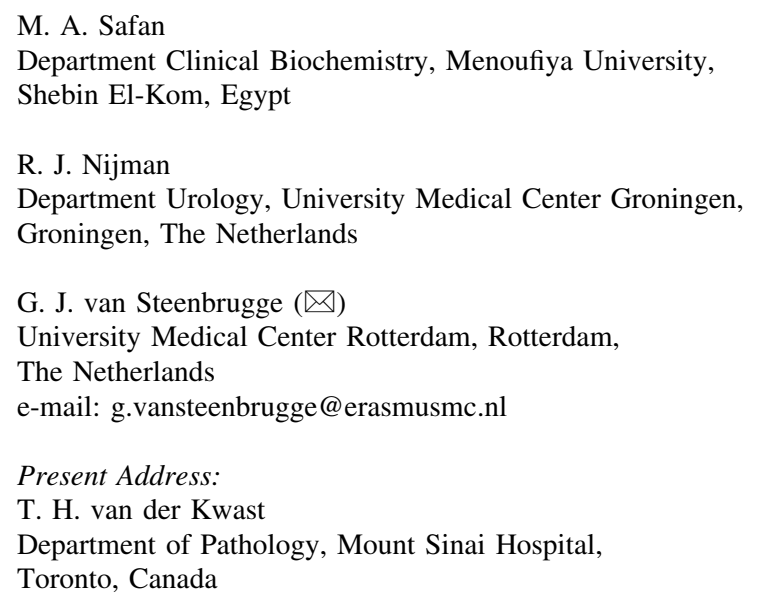


disease, both of which are used to stratify patients to select appropriate modern therapeutic protocols [1,2]. The use of preoperative chemotherapy for WT has become increasingly popular. The International Society of Paediatric Oncology (SIOP) in Europe showed that preoperative therapy facilitated surgery and reduced the frequency of tumour spillage at the time of surgery with good survival outcome [3]. An assumption of the SIOP trials has been that preoperative chemotherapy does not significantly obscure important histopathologic parameters $[4,5]$.

The SIOP approach is different from that of the National Wilms' Tumour Study (NWTS) which does not apply routine preoperative treatment. NWTS investigators believe that preoperative treatment may compromise histological evaluation of the tumour, as well as obscuring tumour stage. Thereby, the ability to optimize subsequent therapy for the appropriate stage and histological type of each patient is compromised as well [6]. However, limited published data are available to give insight into possible differences in the expression patterns of tumour markers in tumours of patients receiving chemotherapy and those who did not. Our survey encompasses the study of a broad panel of tumour markers linked with the biological behaviour of WT. Also, during the course of this study, the research was focused on increasing our knowledge of the expression of various markers and their localization in the tumour and on the selection of markers that might be of prognostic value. In previous studies based on groups of nephroblastoma patients preoperatively treated by chemotherapy, a significant correlation was found between the expression of blastemal WT-1, TGF- $\alpha$, Bcl-2, CD44v5, VEGF, FLT-1, MIB-1 and $\mathrm{p} 27^{\mathrm{kip}-1}$ and clinical progression [7-12].

The purpose of the present study is to reevaluate the expression patterns and the prognostic significance of these tumour markers in a group of preoperatively untreated nephroblastomas and to investigate the effect of chemotherapeutical pretreatment, using immunohistochemistry in paraffin-embedded material. The discussion comments on statistical phenomena that explains the substantial differences in the results reported here compared with those results obtained with studies of chemotherapeutically pretreated patients with classical nephroblastoma which did not display any anaplastic features (Table 1).

\section{Patients and methods}

Patients and sample selection

Forty-three patients with nephroblastoma were treated by tumour nephrectomy and subsequently by chemotherapy, according to the NWTS protocol. All nephrectomy specimens were fixed in $10 \%$ buffered formalin and embedded
Table 1 Expression of antigens factors in preoperatively treated and untreated Wilms' tumour (WT) patients

\begin{tabular}{|c|c|c|c|c|}
\hline \multirow[t]{3}{*}{ Antigen } & \multicolumn{4}{|c|}{$\%$ of positive cases } \\
\hline & \multicolumn{2}{|c|}{ Untreated WT } & \multicolumn{2}{|c|}{ Treated WT [7-12] } \\
\hline & Blastema & Epithelial & Blastema & Epithelial \\
\hline \multicolumn{5}{|c|}{ CD44 isoforms } \\
\hline $\mathrm{CD} 44 \mathrm{~s}$ & $28(65 \%)$ & $24(56 \%)$ & $38(62 \%)$ & $47(77 \%)$ \\
\hline CDD44v5 & $23(54 \%)$ & $17(40 \%)$ & $27(44 \%)$ & $37(61 \%)$ \\
\hline CD44v10 & $21(49 \%)$ & $16(37 \%)$ & $25(41 \%)$ & $25(41 \%)$ \\
\hline \multicolumn{5}{|c|}{ Apoptosis-associated markers } \\
\hline $\mathrm{Bcl}-2$ & $34(79 \%)$ & $31(72 \%)$ & $32(53 \%)$ & $33(54 \%)$ \\
\hline Bax & $21(49 \%)$ & $18(42 \%)$ & $25(41 \%)$ & $27(44 \%)$ \\
\hline Bcl-X & $38(88 \%)$ & $34(79 \%)$ & $23(38 \%)$ & $35(57 \%)$ \\
\hline \multicolumn{5}{|c|}{ Growth factors } \\
\hline TGF- $\alpha$ & $21(49 \%)$ & $24(56 \%)$ & $30(48 \%)$ & $31(50 \%)$ \\
\hline C-erbB2 & $21(49 \%)$ & $26(61 \%)$ & $21(34 \%)$ & $33(53 \%)$ \\
\hline VEGF & $23(54 \%)$ & $26(61 \%)$ & $32(52 \%)$ & $38(61 \%)$ \\
\hline \multicolumn{5}{|c|}{ Growth factor receptors } \\
\hline EGF-R & $22(51 \%)$ & $25(58 \%)$ & $27(44 \%)$ & $37(60 \%)$ \\
\hline Flt-1 & $22(51 \%)$ & $20(47 \%)$ & $29(47 \%)$ & $35(57 \%)$ \\
\hline \multicolumn{5}{|c|}{ Tumour suppressor genes } \\
\hline WT-1 & $20(47 \%)$ & $26(61 \%)$ & $36(59 \%)$ & $35(57 \%)$ \\
\hline $\mathrm{P} 27^{\mathrm{Kip}-1}$ & $18(42 \%)$ & $18(42 \%)$ & $35(57 \%)$ & $45(73 \%)$ \\
\hline \multicolumn{5}{|c|}{ Proliferation marker } \\
\hline MIB-1 & $23(54 \%)$ & $28(65 \%)$ & $38(61 \%)$ & $41(66 \%)$ \\
\hline
\end{tabular}

in paraffin. Tumour staging was done according to the National Wilms' Tumour Staging System [13]. But, the tumour histopathology was assigned according to the adaptation of the revised SIOP working classification of renal tumour of childhood (2001) [14]. Clinical progression was defined as histologically or cytologically proven local recurrence or the appearance of distant metastases. Tumour death was defined as death due to direct effect of metastases.

Clinicopathological data of preoperatively treated Wilms' tumour

In the published work on WT-1, Bcl-2, Bax, and Bcl-X and CD44 isoforms [7, 9, 10], 61 patients were studied. Clinical progression occurred in 14 patients (23\%), and eight patients $(13 \%)$ died from their tumour. The pT-stage distribution was $T_{1}$ in $21, T_{2}$ in 20 and $T_{3}$ in 20 patients. While, in the published work on EGF-R, TGF- $\alpha$, cerbB-2, VEGF and Flt-1 and MIB-1 and p2 $7^{\text {Kip1 }}[8,11,12], 62$ patients with nephroblastoma were studied. Clinical progression occurred in 14 patients $(23 \%)$. Seven patients (11\%) died from their tumour. The pT-stage distribution was $T_{1}$ in 22, $T_{2}$ in 19 and $T_{3}$ in 21 patients (Table 1). 
All the patients were preoperatively treated by neoadjuvant chemotherapy and subsequent tumour nephrectomy. The blastemal cells presented after chemotherapy formed only small foci of blastema. The mean overall follow-up period of both groups was 5.7 years.

\section{Immunohistochemistry}

The PAP (peroxidase-anti-peroxidase) technique was used, which described briefly by Ghanem et al. [7-12]. The studied tumour marker included [CD44 isoforms (CD44s, CD44v5 and $\mathrm{CD} 44 \mathrm{v} 10$ ) apoptosis-associated markers (Bcl-2, Bax, and $\mathrm{Bcl}-\mathrm{X}$ ), growth factors (TGF- $\alpha, \mathrm{C}-\mathrm{er} b \mathrm{~B} 2$ and VEGF), growth factor receptors (EGF-R and Flt-1), tumour suppressor genes (WT-1 and $\mathrm{p} 27^{\mathrm{kip}-1}$ ) and proliferation marker (MIB-1)].

\section{Monoclonal antibody CD31}

The primary monoclonal antibody CD31 (DAKO, A/S, Glostrup, Denmark) was used for the assessment of microvessels density (MVD) in tumour tissues. The immunostaining procedure was similar to that of VEGF [11] with the exception of digestion with $0.1 \%$ trypsin for $10 \mathrm{~min}$ at $37^{\circ} \mathrm{C}$ to substitute antigen exposure enhancement by microwave treatment.

\section{Immunostaining analysis}

The slides were examined at $25 \times$ magnification without knowledge of the clinical outcome of the patients. Immunostaining (nuclear, cytoplasmic or membranous) was calculated as the percentage of positive cells in a particular area: $<10 \% ; 10-25 \% ; 25-50 \%$; $>50 \%$. The specimens were regarded stain positive when the percentage of positive cells was $>10 \%$. The expression of MIB-1, p2 $7^{\text {Kip } 1}$ and microvessels density in cancer cells was evaluated separately as described before [11, 12].

\section{Statistical analysis}

It was performed using the SPSS 11 software package. The association between expression patterns of the various factors and clinico-pathological features was analysed using Pearson chi-square test. The associations between normal kidney, MIB-1 and $\mathrm{p} 27^{\mathrm{Kip} 1}$ PIs (proliferative indices) were studied using the Spearman rank correlation test since the data were not normally distributed. The TGF- $\alpha$, EGF-R, VEGF and Flt-1 staining and their relationship with CD31 counts were analysed by paired sample $t$-test. Univariate analysis using the logrank test for trend was performed. Multivariate analysis was performed using Cox's proportional hazards model with $P<0.05$ considered statistically significant.

\section{Results}

Clinicopathological findings of untreated Wilms' tumour

The patient's distribution was $25(58 \%)$ women and 18 $(42 \%)$ men. The mean age at surgery was 4.2 years, and the mean overall follow-up period was 11.9 years. The T-stage distribution was stage 1 in 22, stage 2 in five, stage 3 in 11 patients, stage 4 in four and stage 5 in one. All the tumour studied was of the classical triphasic type and did not display any anaplastic features. All the patients had intermediate risk tumours. Clinical progression occurred in seven patients (16\%). Five of patients show a relapse within 3 months -2.2 years after initial diagnosis, while two patients having a late relapse between 6.10 and 7.10 years. Two patients $(5 \%)$ died from their tumour. At the end of the follow-up period, 41 patients were alive.

Expression in untreated Wilms' tumour tissue

Normal kidney tissue showed a positive staining of the tubular epithelium for all the studied antibodies and was used as an internal positive control. The percentage of immunoreactive blastemal and epithelial cells in WT cases are listed in Table 1. Blastemal and epithelial Bcl-X and $\mathrm{Bcl}-2$ were observed in the majority of cases. Expression of blastemal CD44s and epithelial MIB-1 was seen in the majority of cases. The other factors (CD44v5, CD44v10, Bax, TGF- $\alpha$, C-erbB2, VEGF, EGF-R, Flt-1, WT-1, $\mathrm{P} 27^{\mathrm{Kip}-1}$ ) showed variable expression in tumour cells. The blastemal and epithelial expressions of all the studied markers were not correlated with clinico-pathological stage of the disease.

MIB-1 and P27 ${ }^{\text {Kip-1 }}$ expression in untreated Wilms' tumours tissues

The mean percentage of MIB-1 and $\mathrm{p} 27^{\mathrm{Kip} 1}$ positive cells in normal renal tissue ranged between 1 and $14 \%$ $(3.4 \% \pm 3.6)$ and $20-75 \%(53 \% \pm 11.9)$, respectively. While in WT tissues, the mean percentage of blastemal and epithelial MIB-1 PI positive cells was $32.8 \% \pm 27.8$ (range $0-80 \%$ ) and $34.1 \% \pm 28.4$ (range $0-85 \%$ ), respectively, whereas for blastemal and epithelial cells, p2 $7^{\mathrm{Kip} 1}$ was $34.8 \% \pm 26$ (range $1-90 \%$ ) and $35 \% \pm 26$ (range 1-80\%), respectively. Eight (19\%) specimens, taken from tumours of various stages, repeatedly showed no labelling with MIB-1 antibody. According to the cutoff point of $10 \%$, MIB-1 positive blastemal and epithelial cells were found in, respectively, 23 (54\%) and 28 (65\%) of the WT studied. Also, p2 $7^{\text {Kip } 1}$ positive blastemal and epithelial cells were found in 18 (42\%) of the WT studied 
(Table 1). The proportion of MIB-1 positive cells relative to $\mathrm{p} 27^{\mathrm{Kip} 1}$ was greater in most specimens. Spearman rank correlation coefficient estimation revealed no significant correlation between blastemal and epithelial p27 $7^{\mathrm{Kip} 1} \mathrm{PI}$ and MIB-1 PI.

MVD and its correlation with TGF- $\alpha$, EGF-R, VEGF and Flt-1 expression

Microvessels were defined by the presence of CD31stained capillaries or small clusters of CD31-positive cells. Microvessel count ranged from 3 to 90 with a mean of 43.3 (SD, 30). The number of vessels counted in TGF- $\alpha$, VEGF and Flt-1 blastemal and epithelial positive tumours was significantly greater than that in the negative tumours (Table 2). EGF-R expression in the tumour cells did not

Table 2 Correlation between MVD and TGF- $\alpha$, EGFR, VEGF and Flt-1 expressions in untreated Wilms' tumour group

\begin{tabular}{|c|c|c|}
\hline & \multicolumn{2}{|l|}{ MVD } \\
\hline & Mean \pm SD & $P$ value \\
\hline \multicolumn{3}{|l|}{ TGF- $\alpha$} \\
\hline \multicolumn{3}{|l|}{ Blastema } \\
\hline Negative & $33.7 \pm 29.3$ & \\
\hline Positive & $53.2 \pm 28.6$ & $<0.05^{*}$ \\
\hline \multicolumn{3}{|l|}{ Epithelial } \\
\hline Negative & $31.8 \pm 30.2$ & \\
\hline Positive & $52.3 \pm 27.7$ & $<0.05^{*}$ \\
\hline \multicolumn{3}{|l|}{ EGF-R } \\
\hline \multicolumn{3}{|l|}{ Blastema } \\
\hline Negative & $39.9 \pm 32.3$ & \\
\hline Positive & $46.5 \pm 28.6$ & $>0.05^{*}$ \\
\hline \multicolumn{3}{|l|}{ Epithelial } \\
\hline Negative & $41.7 \pm 33.1$ & \\
\hline Positive & $44.4 \pm 28.7$ & $>0.05^{*}$ \\
\hline \multicolumn{3}{|l|}{ VEGF } \\
\hline \multicolumn{3}{|l|}{ Blastema } \\
\hline Negative & $28.5 \pm 26.5$ & $<0.05^{*}$ \\
\hline Positive & $56.1 \pm 27.9$ & \\
\hline \multicolumn{3}{|l|}{ Epithelial } \\
\hline Negative & $26.7 \pm 27.1$ & $<0.05^{*}$ \\
\hline Positive & $54.1 \pm 27.7$ & \\
\hline \multicolumn{3}{|l|}{ Flt-1 } \\
\hline \multicolumn{3}{|l|}{ Blastema } \\
\hline Negative & $31.6 \pm 27.5$ & \\
\hline Positive & $54.4 \pm 29.2$ & $<0.05^{*}$ \\
\hline \multicolumn{3}{|l|}{ Epithelial } \\
\hline Negative & $34.2 \pm 31$ & \\
\hline Positive & $53.7 \pm 26.7$ & $<0.05^{*}$ \\
\hline
\end{tabular}

show a significant correlation with MVD, however. The high vascularization foci occurred most frequently within the tumour stroma. However, some cases were high in MVD despite being TGF- $\alpha$, EGF-R, VEGF and Flt-1 negative, and some cases were low in MVD although they were TGF- $\alpha$, EGF-R, VEGF and Flt-1 positive (data not shown).

Prognostic value of these molecules

Univariate analysis using the logrank test for trend showed a prognostic value of blastemal WT-1, TGF- $\alpha$, VEGF, MIB-1 and $\mathrm{p} 27^{\mathrm{Kip} 1}$ expression for clinical progression. Neither the epithelial expression of all markers studied nor MVD did not show any prognostic value. A multivariate Cox' regression analysis was done using the stage, and WT-1, TGF- $\alpha$, VEGF, MIB-1 and $\mathrm{p} 27^{\mathrm{Kip} 1}$ expression as parameters. The parameters that were not dichotomic were dichotomized as follows: stage 1, 2 versus stage 3, 4, 5; immunoreactive score $<10 \%$ versus $>10 \%$ and MIB-1 was classified as PI $<5 \%$ versus $>5 \%$; and for $\mathrm{p} 27^{\mathrm{KIP} 1}$ as PI $<50 \%$ versus $\mathrm{PI}>50 \%$. In that analysis, blastemal WT-1 could be identified as an independent prognostic marker for clinical progression.

\section{Discussion}

Wilms' tumour is a malignant disease well known for its unpredictable course and tendency of tumour recurrence or metastasize, sometimes years after primary treatment [13, 14]. Since tumour metastasis is the principle cause of death for cancer patients, there is consensus that a search for tools that allow effective assessment of metastatic potential of tumours is a primary goal for cancer research. It is well established that preoperative chemotherapy can reduce the morbidity [6]. The possibility that such therapy may obscure or alter important prognostic features such as anaplasia and pathologic stage, however, has remained a concern $[15,16]$. The aim of this study was to investigate the expression of a broad panel of tumour markers at the protein level in a group of specimens of untreated clinical nephroblastoma, using paraffin-embedded tissue sections. Results were compared with those obtained in a pretreated group of patients.

The level of expression (intensity) or proportion of positive cells was higher for most of the markers in the untreated patients compared to the treated WT patients (Table 1). The association between expression of prognostic marker and the surgical stage could not be shown. This is probably due to the disproportionate stage distribution of the cases in this relatively small group of patients, as 22 of the 43 cases $(51 \%)$ were stage 1 . In general, the 
data of the preoperatively untreated group demonstrate that the expression of most of the tumour markers has the same trend for clinical progression as in the treated group studies before [7-12]. In this series, no correlation between any tumour markers and survival was demonstrated, as only 2 (5\%) patients died of disease. Because of the difference between SIOP and NWTS protocols, stage-for-stage outcome comparisons between these two studies could not be performed [17].

The mean percentage of blastemal and epithelial MIB-1 was higher in the untreated group when compared to the treated group of patients. The contrary applies to the $\mathrm{P} 27^{\mathrm{Kip}-1}$ expression, i.e. its expression level was lower in the untreated compared to the treated group [12] (Table 1). These observations confirmed previous studies correlating proliferating cell nuclear antigen (PCNA) labelling scores with the effect of therapy in WT [18]. In this study, it was shown that chemotherapeutic manipulation of tissues resulted in decreased PCNA staining in WT cell cultures exposed to dexamethasone and cyclosporin A [19].

The expression of both Bcl-2 and Bax in untreated group was similar to those reported for the preoperatively treated group [9] (Table 1). Remarkably, in the untreated series, Bcl-X expression was found in $88 \%$ of the tumours. These results are similar to those reported for prostatic and gastric cancer, in which Bcl-X immunoreactivity was found in 100 and $85 \%$ of the tumours, respectively $[20,21]$. The percentage of Bcl-X was relatively high in comparison with the preoperatively treated group, in which blastemal Bcl-X immunoreactivity was found in only $38 \%$ of the tumours. It is tempting to speculate that immunohistochemical expression of the single marker, Bcl-X, might be a useful parameter to predict chemo- or radiosensitivity of tumours at the start of therapy (Table 1). Generally, chemotherapy of WT leads to a selection of tumour cells, which are not in cell cycle, because it knocks out the proliferative cohort of cells. On the other hand, chemotherapeutical treatment may also lead to an enhanced apoptotic response of tumour cells. Such a response is determined by the expression of various apoptotic proteins which either promotes (Bax, $\mathrm{Bcl}-\mathrm{Xs})$ or block $\left(\mathrm{Bcl}-2, \mathrm{Bcl}-\mathrm{X}_{\mathrm{L}}\right)$ the potency of tumour cells to undergo apoptosis. Strong expression of markers that block the apoptotic process leads to drug resistance.

With regard to angiogenesis, TGF- $\alpha$, VEGF and Flt-1 expression in tumour cells was significantly correlated with the MVD in untreated WT. In general, in these patients, the overall scores of the expression levels of TGF- $\alpha$, VEGF and Flt-1 in the blastemal and epithelial components were higher, but these patients had a similar clinical outcome compared to that in patients of the pretreatment group [11] (Tables 1, 2). These results indicate that in untreated WT counting of microvessels in the tumour shows correlation with other angiogenic factors [22, 23].
In multivariate analysis, the tumour suppressor gene product, WT-1, expressed by blastemal tissue in untreated group, was the only independent prognostic marker for clinical progression. The prognostic impact of WT-1 expression at the protein level was confirmed by a study based on cDNA microarray analysis [24]. This is in contrast to the preoperatively treated group, in which blastemal p27 was the strongest independent prognostic marker for clinical progression [12]. This difference may be attributed to the effect of chemotherapy, but the small number of untreated cases and their skewed distribution of T-stage or over-representation of stage I patients may also have influenced this outcome.

In summary, most factors studied in a group of untreated WT patients were expressed in the blastemal as well as in the epithelial compartment. In contrast to the expression in blastema, none of the epithelium-localized factors had any prognostic value, however. Apparently, blastemal-bound expression of particular markers has a much stronger prognostic impact than their expression in the epithelium. However, future approaches in WT studies of the tumour marker need to be multidisciplinary, biochemical, cytogenetic as well as molecular genetic, optimally the usefulness of these markers $[25,26]$. So, WT patients might benefit from the evaluation of these markers to more precisely estimate the need for adjuvant chemotherapy and/or radiotherapy.

Conflict of interest The authors declare that they have no conflict of interest.

Open Access This article is distributed under the terms of the Creative Commons Attribution Noncommercial License which permits any noncommercial use, distribution, and reproduction in any medium, provided the original author(s) and source are credited.

\section{References}

1. Beckwith JB, Palmer NF (1978) Histopathology and prognosis of Wilms' tumour. Cancer 41:1937-1948

2. Breslow NB, Churchill G, Beckwith JB, Fernbach DJ, Otherson HB, Tefft M, D'Angio GJ (1985) Prognosis for Wilms' tumour patients with nonmetastatic disease at diagnosis: results of the Second National Wilms' Tumour Study. J Clin Oncol 3:521-531

3. Lemerle J, Voute PA, Tournade MF, Delemarre JF, Jereb B, Ashtrom L, Flamant R, Gerard-Marchant R (1976) Preoperative versus postoperative radiotherapy, single versus multiple courses of actinomycin $\mathrm{D}$, in the treatment of Wilms' tumour: preliminary results of a controlled clinical trial conducted by the International Society of Paediatric Oncology (SIOP). Cancer 38:647-654

4. Burger D, Feickert HJ, Mildenberger H (1986) Current status of nephroblastoma treatment. Malignant neoplasms in childhood. Karger, New York, pp 224-242

5. Lemerle J, Voûte PA, Tournade MF, Rodary C, Delemarre JF, Sarrazin D, Burgers JM, Sandstedt B, Mildenberger H, Carli M, Jereb B, Moorman-Voestermans CGM (1983) Effectiveness of preoperative chemotherapy in Wilms' tumour: Results of an 
international Society of Paediatric Oncology (SIOP) clinical trial. J Clin Oncol 10:604-609

6. D'Angio GJ (1983) SIOP and the management of Wilms' tumour. J Clin Oncol 1:595-596

7. Ghanem MA, van der Kwast ThH, Den Hollander JC, Sudaryo MK, Monique HA, Noordzij MA, van den Heuvel MM, Shoukri MN, Nijman RJM, van Steenbrugge GJ (2000) Expression and prognostic value of Wilms' Tumour 1 and early growth response 1 proteins in nephroblastoma. Clin Cancer Res 6:4265-4271

8. Ghanem MA, van der Kwast ThH, Den Hollander JC, Sudaryo MK, Rejiv BM, van den Heuvel MM, Noordzij MA, Nijman RJM, van Steenbrugge GJ (2001) Expression and prognostic value of epidermal growth factor receptor, transforming growth factor- $\alpha$, and c-erbB-2 in nephroblastoma. Cancer 92:3120-3129

9. Ghanem MA, van der Kwast ThH, Den Hollander JC, Sudaryo MK, van den Heuvel MM, Noordzij MA, Nijman RJM, Soliman EH, van Steenbrugge GJ (2001) The prognostic significance of apoptosis-associated proteins Bcl-2, Bax, and Bcl-X in clinical nephroblastoma. Br J Cancer 85:1557-1563

10. Ghanem MA, van Steenbrugge GJ, van der Kwast ThH, Sudaryo MK, Noordzij MA, Nijman RJM (2002) Expression and prognostic value of CD44 isoforms in Nephroblastoma (Wilms' tumour). J Urol 168:681-686

11. Ghanem MA, van Steenbrugge GJ, Sudaryo MK, Mathoera RB, Nijman JM, van der Kwast ThH (2003) Expression and prognostic value of vascular endothelial growth factor (VEGF) and its receptor (Flt-1) in nephroblastom. J Clin Pathol 56:107-113

12. Ghanem MA, van der Kwast ThH, Sudaryo MK, Mathoera RB, Al-Doray AM, Nijman RJM, van Steenbrugge GJ (2004) MIB-1 (Ki-67) Proliferation index and cyclin dependent kinase inhibitor P27 ${ }^{\text {kip } 1}$ in nephroblastoma. Clin Cancer Res 10:591-597

13. D'Angio GJ, Breslow W, Beckwith JB, Evans A, Baum H, DeLorimer A, Fernbach D, Hrabovsky E, Jones B, Kelalis P, Othersen B, Tefft M, Thomas R (1989) Treatment of Wilms' tumour: results of the Third National Wilms' Tumour Study. Cancer 64:349-360

14. Vujanic GM, Sandstedt B, Harms D, Kelsey A, leuschmer I, de Kraker J (2002) Revised International Society of Paediatric Oncology (SIOP) working classification of renal tumours of childhood. Med Paediatr Oncol 38:79-82

15. van Leewen EH, Postma A, Oesterhuis JW, Meiring A, Koudstaal J, Molenaar WM (1987) An analysis of histology and DNAploidy in primary Wilms' tumours and their metastases and a study of the morphological effects of therapy. Virchows Arch 410:487-494
16. Guarda LA, Ayala AG, Jaffe N, Suttow WW, Bracken RB (1984) Chemotherapy-induced histologic changes in Wilms' tumours. Pediatr Pathol 2:197-206

17. de Kraker J, Weitzman S, Voûte PA (1985) Preoperative strategies in the management of Wilms' tumour. Hematol Oncol Clin North Am 9:1275-1285

18. Hall PA, Levison DA, Woods AL, Yu CC, Kellock DB, Watkins JA, Barnes DM, Gillett CE, Camplejohn R, Dover R, Waseem NH, Lane DP (1990) Proliferating cell nuclear antigen (PCNA) immunolocalization in paraffin sections: an index of cell proliferation with evidence of deregulated expression in some neoplasms. J Pathol 162:285-294

19. Kurki P, Vanderlaan M, Dolbeare F, Gray J, Tann EM (1986) Expression of proliferating cell nuclear antigen (PCNA/Cyclin) during the cell cycle. Exp Cell Res 166:209-219

20. Krajewska M, Fenoglio Preiser CM, Krajewski S, Song K, Macdonald JS, Stemmermann G, Reed JC (1996) Immunohistochemical analysis of Bcl-2 family proteins in adenocarcinomas of the stomach. Am J Pathol 149:1449-1457

21. Krajewska M, Krajewski S, Epstein JI, Shabaik A, Sauvageot J, Song K, Kitada S, Reed JC (1996) Immunohistochemical analysis of bcl-2, bax, bcl-X, and mcl-1 expression in prostate cancers. Am J Pathol 148:1567-1576

22. Nowicki M, Ostalska-Nowicka D, Kaczmarek M, Miskowiak B, Witt M (2007) The significance of VEGF-C/VEGFR-2 interaction in the neovascularization and prognosis of nephroblastoma (Wilms' tumour). Histopathology 50:358-364

23. Ozluk Y, Kilicaslan I, Gulluoglu MG, Ayan I, Uysal V (2006) The prognostic significance of angiogenesis and the effect of vascular endothelial growth factor on angiogenic process in Wilms' tumour. Pathology 38:408-414

24. Takahashi M, Yang X, Lavery T, Furge K, Williams B, Tretiakova M, Montag A, Vogelzang N, Re G, Garvin A, Soderhall S, Kagawa S, Hazel-Martin D, Nordenskjold A, Teh B (2002) Gene expression profiling of favourable histology Wilms' tumours and its correlation with clinical features. Cancer Res 62:6598-6605

25. Fridman E, Pinthus JH, Kopolovic J, Ramon J, Mor O, Mor Y (2006) Expression of cyclooxygenase-2 in Wilms' tumour: immunohistochemical study using tissue microarray methodology. J Urol 176:1747-1750

26. Bien E, Balcerska A, Kuchta G (2007) Serum level of soluble interleukin-2 receptor alpha correlates with the clinical course and activity of Wilms' tumour and soft tissue sarcomas in children. Biomarkers 12:203-213 